\title{
ФАКТЧЕКІНГ ЯК ІНСТРУМЕНТ ПРОТИДІЇ МАНІПУЛЯТИВНОМУ ВПЛИВУ ЕЛЕКТРОННИХ ЗМІ
}

\author{
Юлія Кияшко \\ Наиіональний університет державної фіскальної служби Украӥни, \\ вул. Університетська, 31, 08201, м. Ірпінь, Київська область, Україна \\ e-mail: kiyashkoupp@ukr.net \\ https://orcid.org/0000-0002-2110-3565
}

У статті проаналізовано основні ресурси та їх діяльність щодо верифікації та фактчеку контенту в інформаційному полі в період передвиборчих перегонів. Увагу зосереджено на маніпулятивних елементах, які використовують медіатворці задля задоволення інформаційних потреб аудиторії. Запропоновано систему рекомендацій під час перевірки правдивості інформації в електронних медіа для споживачів медійного продукту.

Ключові слова: брехня, верифікація, глибокий фейк, маніпуляція, медіаграмотність, фактчек, фейк.

Сучасний інформаційний простір схожий на поле бою, де основним інструментом виступають слова і образи, за допомогою яких маніпулятори формують думку аудиторії, а відтак і спонукають суспільство до вигідних дій. Засоби масової інформації слугують рупором думок можновладців, експертів, громад. Медіа сьогодні це загрозлива зброя, що здатна уразити думку широких мас, вплинути на прийняття рішень людей у виборі лідера країни, спонукати до дій, подекуди агресивних та небезпечних. Інформаційний простір у передвиборчих баталіях перетворюється мало не на справжній бойовий майданчик, де професійні журналісти, а разом 3 ними й ціла гвардія досвідчених політтехнологів, покликаних привести до перемоги «свого» кандидата будь-якою ціною, творять історію з фактів, маніпуляцій, фактоїдів, брехні та неправди.

Проблема заангажованості ЗМІ спонукає до пошуку істини для медіаюзерів. Аудиторія потребує роз'яснень та допомоги через відсутність медіакомпетентності. Перш за все це пов'язано 3 тенденцією антиукраїнської пропаганди в умовах політичних взаємостосунків України на міжнародній арені. Зважаючи на швидкі темпи розповсюдження фейкових повідомлень та оптимальне середовище для культивації цілих джерел, покликаних щоденно творити потоки інформаційної війни, професійні українські журналісти вдалися до розслідувань. Зокрема, завдяки західному досвіду перевірки фактів у медіасередовищі спостерігаємо концепт фактчек - потужний, дієвий інструмент викриття політичних маніпуляцій та фактичних спекуляцій на

(C) Кияшко Ю., 2019 
болючих соціальних темах, яскравий засіб демонстрації реальної компетенції політиків та чиновників, платформа для глибоких розслідувань, підкріплених фактами з відкритих джерел, що практично унеможливлює звинувачення в заангажованості та суб'єктивності [1, с. 6].

Аналіз останніх досліджень з проблематики роботи свідчить про підвищений інтерес науковців і дослідників, а також журналістів-практиків до способів викриття неправдивого контенту у медіапросторі. Українські медійники, спираючись на систему та алгоритми фактчеку та верифікації західних мас-медіа, пропонують власні стратегії виявлення брехні та роботи з перевіркою фактів. На цій ниві активну роботу ведуть журналісти фактчекінгових проектів в Україні, що викривають брехню та маніпуляції у заявах політиків, VoxCheck [2], Stopfake.org [3], Без Брехні [4]. Теоретичні засади сформовані у працях О. Гороховського [1], Г. Почепцова [5], О. Юркової [6] та інших. Метою нашої розвідки вбачаємо аналіз концепту фактчеку, що сьогодні використовують некомерційні організації, а зокрема розгляд алгоритму викриття маніпулятивних технік наряду із правдою, напівправдою та брехнею.

Актуальність фактчекінгу набирає обертів у всьому світі, оскільки маніпулятивні технології мають всі передумови для розвитку і вдосконалення: стрімкий технічний прогрес, можливості оперативного аудіовізуального виробництва, трансформація класичних принципів діяльності мас-медіа у поле соціальних мереж 3 певними потребами і характерними поведінковими факторами. Все це дає привід для занепокоєння у боротьбі не просто $з$ викривленими фактами, а й «глибокими фейками» (так звані Deep Fakes). «Нові технології дозволяють створювати цілком реалістичні зображення. Поки це в основному прерогатива Голлівуду, але не за горами час, коли відеоролик, в якому, наприклад, британський прем'єр Тереза Мей підносить хвалу російському президенту, може бути створений чи не кожним бажаючим», - висловлюють занепокоєння дослідники через тривожну тенденцію поширення фальшивих новин у світі [7].

Так, глядачі вже мали можливість спостерігати за технологічним творінням Вашингтонських дослідників, які продемонстрували всьому світу на прикладі промови колишнього президента США Барака Обами [8], що Deep Fakes вже сьогодні є реальністю. Президент нібито звертається до людей з проблемою фейкових новин. Насправді кінорежисер Джордан Піл вкладає свої слова у промову Обами і технічно це виглядає дуже реалістичним.

У всьому світі медіафахівці спрямовують сили на створення й вдосконалення ресурсів, що дозволятимуть виявляти відео- та аудіофейки - найбільш ефективні та впливові з психологічної точки зору. Авторитетні диджитал корпорації ведуть активні розробки програмного забезпечення задля виявлення та ідентифікації синтетичного відео. Проте фахівці зазначають, що інструменти, які допомагають знайти «глибокі фейки», практично відсутні, а вчені, журналісти та технологічні компанії намагаються якнайшвидше їх створити [9].

Натомість ми швидко у вільному доступі знаходимо програмне забезпечення, за допомогою якого пересічний користувач за потреби зможе створити відео у стилі Deep Fake. Це, наприклад, програмне забезпечення FakeApp, позиціонує себе як десктопний додаток, що дозволяє легко створювати фотореалістичні відеороліки, в яких оригінальні обличчя замінені на обличчя інших людей [10]. 
Світова тенденція боротьби з маніпуляціями та фейками на сторінках web-видань та в ефірі електронних традиційних ЗМІ в українському медіапросторі посилюється через російську експансію, що серед основних інструментів гібридної війни використовує інформаційну протидію.

На варті верифікації сьогодні стоять аналітичні ресурси, створені 3 метою незаангажовано, чесно, неупереджено здійснювати фактчек новин, заяв політиків та впливових для розвитку країни осіб. Сучасні медіа, що фінансуються за кошти олігархів, не можуть залишатися об'єктивними в аналітиці подій, процесів та політичних прогнозів. Тому спостерігаємо створення організацій некомерційного вектору, що намагаються зберігати фінансову незалежність і неупередженість думок за рахунок залучення провідних світових авторитетних експертів, альтернативних засобів фінансування. Серед провідних організацій, що здійснюють фактчек в Україні є такі:

- «VoxUkraine» - більше, ніж краща аналітика про Україну - розвиває перший фактчекінговий проект в Україні VoxCheck, який виявляє брехню і маніпуляції в заявах політиків. Організація наголошує на тому, що є некомерційною організацією, що фінансується за рахунок благодійних внесків сотень людей, яким небайдужа доля України, а також грантів донорських організацій [2];

- «Stopfake.org» - боротьба з неправдивою інформацією про події в Україні основна діяльність направлена на боротьбу з антиукраїнською пропагандою, заявами і фактами, спрямованими на дискредитацію України [3];

- «Без брехні» - фактчек політичної риторики - аналітична платформа, фахівці якої, крім того, що аналізують заяви українських політиків та можновладців за класичною методикою фактчек, розробляють нові підходи і формати фактчеку, здійснюють аналітичну діяльність у цьому напрямку, просувають фактчек у регіони країни шляхом проведення тренінгів [4];

- «Слово і Діло» - аналітичний портал - це перший фактчек-ЗМІ в Україні, що ставить за мету забезпечити реалізацію принципу транспарентності й підзвітності влади, сприяти зростанню рівня відповідальності політиків і посадових осіб перед громадянами. Ключовим аспектом роботи «Слова і Діла» $є$ визначення рівня відповідальності вітчизняних політиків та посадових осіб на підставі систематичного моніторингу та фіксації їхніх обіцянок, а головне - відстеження стану їх виконання [11].

Як бачимо, основною метою ресурсів є перевірка і спростування перекрученої інформації про те, що відбувається в Україні і пропаганди в ЗМІ, яка поширюється. Лише за останній рік, наприклад, в межах проекту VoxCheck було проаналізовано та перевірено на предмет викривлення інформації 1962 висловлювання. «Більше половини в них - маніпуляції, брехня та перебільшення», - стверджують експерти проекту «Рейтинг маніпуляторів та брехунів» за 2018 рік. Весь рік фактчекінговий проект VoxCheck перевіряв висловлювання очільників держави та політиків, які лідирують в соціологічних опитуваннях до президентських та парламентських виборів [12].

Фактчекри відзначають, що алгоритм викриття неправдивої інформації у різних редакціях хоча і має відмінності, проте концептуально базується на ключових моментах, що відрізняе фактчек від класичної схеми журналістського розслідування. Передусім це - повна відмова, принципове невикористання в доказовій базі інсайдерської та неофіційної інформації. Для побудови дослідження фактчек користується тільки офіційними джерелами інформації, як українськими, так і зару- 
біжними, відповідями на запити в держоргани та зарубіжні інституції. Коментарі та експертні висновки використовуються в доказовій базі тільки в тому випадку, якщо вони спираються на документальні свідчення та дані з відкритих джерел [1, с. 24]. Натомість розслідування дослідники характеризують як синтетичний метод роботи, що об’єднує всі методи збору інформації журналістом (спостереження, інтерв'ю, аналіз документів), заснований на роботі з численними джерелами, ретельному аналізі, порівнянні, пошуку протиріч і прихованих відомостей з метою оприлюднення інформації, представляє суспільний інтерес [13, с. 6].

Олексій Набожняк, викладач Могилянської школи журналістики та експерт фактчекінгового ресурсу StopFake, розповідаючи про інструменти фактчеку, пропонує наступний алгоритм, що допомагає швидко і ефективно ловити політиків на брехні та спростовувати фальшиві новини.

1. Обрати матеріал і виділити з нього твердження, що потребують перевірки, обрати якомога оперативніший та якісніший спосіб перевіряння;

2. Пошукати в авторитетних джерелах інформації підтвердження, що допоможуть класифікувати повідомлення як правдиве, неправдиве, оманливе або таке, що не можна перевірити;

3. Відібраний і проаналізований факт супроводжується коментарем, у якому аргументується вибір перевірки саме цього факту та їі результат;

4. Експерт перевіряє коментар - якість і надійність джерела, відповідність класифікації;

5. Якщо коментар проходить перевірку, здійснюється перехресний фактчекінг (фінальна перевірка на внутрішню логіку); якщо ні - дослідник виправляє коментар, враховуючи зауваження експерта;

6. Залучення зовнішнього експерта, який, якщо це потрібно, оцінює текст;

7. Публікація перевірених даних. Публікуючи їх, слід посилатись на джерела перевірки та експертів [14].

Медіатренерка, наукова співробітниця Центру Тоу Колумбійського Університету Клэр Вардл, досліджуючи інфопростір соціальних медіа, небезпечний своєю доступністю для широких мас, де автором може стати будь-хто і вдатися до маніпулятивних дій з інформацією, радить дотримуватись рекомендацій щодо перевірки контенту у соціальних медіа, перевірити та підтвердити чотири елементи:

1. Походження: чи дійсно це оригінальний фрагмент контенту?

2. Джерело: Хто завантажив контент?

3. Дата: Коли контент було створено?

4. Місце розташування: Де було створено контент [15, с. 25]?

Фактчекінг - перевірка тверджень на повноту, достовірність та наявність маніпуляцій - не лише захищає суспільство від брехні, а й допомагає виховати в громадян критичне мислення, змусити політиків відповідати за свої слова, поліпшує якість політичної дискусії.

Серед відвертої брехні, до якої вдаються політики нерідко у промовах та зверненнях, фіксують маніпулятивні техніки спікерів. У роботі професійних фактчекерів стоїть більше завдань, ніж перед мадіаюзером, якого закликають здійснювати найпростіші кроки, щоб залишатись медіаграмотним та активізувати критичне мислення. Фактчекеру знадобляться вміння та навички не лише відрізнити правду від брехні, а й ідентифікувати маніпулятивні прийоми. Зважаючи на схильність ши- 
рокої аудиторії до позитивного ставлення до завідомо маніпулятивних заяв через інформаційну необізнаність, стереотипність сприйняття фактів та впливових фігур, перманентне суспільне напруження в країні, яке притуплює критичність мислення, саме промови і виступи публічних осіб стають об'єктом дослідження, а також бекграунд гучних подій, що супроводжується коментарями та оціночними судженнями. Так, наприклад, одним 3 найскладніших завдань фактчеку команда проекту «Без Брехні» вбачає роботу з популістською риторикою через те що спікери-популісти використовують в промовах не стільки реальні факти, скільки гасла та певні штампи, а тези містять відверто суб'єктивні ознаки [1].

Варто зазначити, що протистояти хвилям дезінформації під силу й пересічним споживачам інформації. Вищезазначені рекомендації від західних колег щодо поведінки користувачів соціальних мереж, за умови дотримання їх, здатні підвищити рівень медіаграмотності нашого вразливого та довірливого суспільства. Дослідники спостерігають, що користувачі, отримавши доступ до великих обсягів інформації, не вміють критично сприймати їі. I на сьогодні завданням $\epsilon$ навчити орієнтуватись людей у медіапросторі, особливо похилого віку, формування свідомості яких відбувалось у тотальній довірі ЗМІ. На цьому наголошує експерт з інформаційної політики та комунікаційних технологій Г. Почепцов: «Цікаво, що люди старші 65 років роблять репости фейків в два рази частіше, ніж люди з попередньої вікової категорії від 45 до 65 років. А порівняння з групою від 18 до 29 років показало, що люди старшого віку роблять це майже в сім раз частіше» [16].

На нашу думку робота із підвищення медіаграмотності людей різного віку $є$ вкрай важливою, особливо у періоди активізації політичних протистоянь. Звичайно, розглянуті вище алгоритми перевірки фактів, а особливо викриття напівбрехні та ідентифікації маніпулятивних заяв залишатиметься прерогативою професійних фактчекерів. Проте дотримання елементарних правил задля збереження медіагігієни у повсякденному просторі кожного медіаюзера є необхідним.

Отже, серед найбільш уразливих компонентів контенту, що здатні ввести в оману, на нашу думку є такі:

- інтерпретація візуальної складової,

- маніпулятивне формулювання заголовку матеріалу,

- завуальоване/приховане джерело або відсутність посилання на джерело.

Ця система лягла в основу сценарію відеоінструкції, створеної нами з метою підвищення рівня обізнаності громадян щодо поведінки медіаюзерів у глобальній мережі. Так, відеосюжет на тему: «Способи перевірки правдивості інформації в інтернеті - інструкція для медіаюзерів» був створений в межах проекту «re:start democratic discourse», що втілювався протягом червня-грудня 2018 року IPРП ( $\mathrm{IH}^{-}$ ститутом розвитку регіональної преси) в партнерстві з Європейським центром свободи преси та 3MI (ECPMF), м. Лейпциг, за підтримки Міністерства закордонних справ Німеччини та трансльований у регіональних медіа Запорізької області («БМТ «ТБ-Бердянськ» БМР», ефірна довідка від 21 листопада 2018; ТРК «Лавіна», ефірна довідка від 22 листопада 2018) [17].

Вважаємо, що подібні заходи сприятимуть розвитку українського інформаційного медіапростору в умовах інформаційної війни як всередині країни, так і в загостреному комунікаційному процесі із іншими державами. 
Проаналізувавши основні концепти фактчеку в сучасному українському медіапросторі доходимо висновку, що на сьогодні триває процес удосконалення алгоритму фактчеку та верифікації різними провідними організаціями, що здійснюють перевірку і викриття брехні та маніпуляцій у заявах публічних осіб та політиків. В умовах активного інформаційного протистояння вектори діяльності експертів у цій галузі набувають все більше чітких орієнтирів, проте відзначаємо різні підходи як у методах та техніках фактчекінгу, так і об'єктах верифікації.

Проблемою залишається зворотній зв'язок із аудиторією, що загалом має низький рівень медіаграмотності в країні. Лише за допомогою незаангажованих і незалежних професійних галузевих експертів, що намагаються робити якісну аналітику та в цьому контексті відрізняти правду від брехні та маніпуляцій, можливий розвиток нових світових і українських медіа зокрема. Тож питання пошуку оптимальних форм і методів розповсюдження рекомендацій та інструкцій правильного споживання інформаційних потоків, а також вдосконалення алгоритму фактчеку складних маніпулятивних заяв залишається актуальним і потребує подальших досліджень.

\section{REFERENCES}

1. Гороховський О. Фактчек як тренд розслідувань: можливості та перспективи: практичний посібник / О. Гороховський. Дніпро: ЛІРА, 2017. 133 с.

2. VoxCheck [Електронний ресурс] - Режим доступу до ресурсу: https://voxukraine. org/ru/authors-ru/

3. Stopfake.org [Електронний peсурc] - Режим доступу до ресурсу: https://www. stopfake.org/

4. Без Брехні [Електронний ресурс] - Режим доступу до ресурсу: http://bez-brehni. com

5. Почепцов Г. Фейк. Технології спотворення реальності / Г. Почепцов. Київ: Видавничий дім «Києво-Могилянська академія», 2018. 175 с.

6. Юркова О. Шесть способов создания фейковых новостей и простые инструменты для их разоблачения [Електронний ресурс] / Ольга Юркова. 2018. - Режим доступу до ресурсу: https://tinyurl.com/yyxtwk78

7. Смотряев М. Что такое глубокие фейки и как с ними бороться [Електронний ресурс] / Михаил Смотряев. 4 апреля 2018. - Режим доступу до ресурсу: https:// www.bbc.com/russian/features-43645446

8. Fake Obama created using AI tool to make phoney speeches [Електронний peсурс]. 17 Jul 2017. - Режим доступу до pecypcy: https://www.bbc.com/news/av/ technology-40598465/fake-obama-created-using-ai-tool-to-make-phoney-speeches

9. Санн С. Чего ждать от грядущей волны «глубоких фейковых видео» [Електронний ресурс] / Саманта Санн. October 30, 2018. - Режим доступу до ресурсу: http:// clc.am/yWpWIA

10. FakeApp. Нейросеть, меняющая лица в видео [Електронний ресурс]. 2018. - Режим доступу до ресурсу: https://fakeapp.site/

11. Слово і діло [Електронний ресурс] - Режим доступу до ресурсу: https://www. slovoidilo.ua/pro-proekt

12.Брехня-2018. Як кандидати в президенти та лідери партій брехали та маніпулювали у передвиборчий рік. Рейтинг маніпуляторів та брехунів VoxCheck 
[Електронний ресурс]. 2019. - Режим доступу до ресурсу: https://voxukraine.org/ longreads/lie-2018/index.html.

13. Посібник з журналістських розслідувань. Теорія та практика / Б. Бєль, О. Бурмагін, Т. Патора, О. Хоменок. Київ: Друкарня Бізнесполіграф, 2013. 190 с.

14. Інструменти фактчекінгу: як професійно відрізняти брехню від правди [Електронний ресурс]. 2016. - Режим доступу до pecypcy: https://imi.org.ua/articles/ instrumenti-faktchekingu-yak-profesiyno-vidriznyati-brehnyu-vid-pravdi/

15. Вардл К. Перевірка контенту, отриманого від читачів / Клэр Вардл // Посібник 3 Верифікаці / Крейг Сільверман. Свропейський центр журналістики, 2014. 128 с.

16. Почепцов Г. Соцмедиа создают свой мир: сначала информационный, а потом - и физический [Електронний ресурс] / Георгий Почепцов. 2019. - Режим доступу до pecypcy: https://ms.detector.media/trends/1411978127/sotsmedia_sozdayut_svoy_mir_ snachala_informatsionnyy_a_potom_i_fizicheskiy/

17. Кияшко Ю. Способи перевірки правдивості інформації в інтернеті - інструкція для медіаюзерів [Електронний ресурс] / Юлія Кияшко. 2018. - Режим доступу до pecypcy: https://www.youtube.com/watch?v=yYQ-i_0a6Mw 


\title{
FACTCHECKIHG AS AN INSTRUMENT WHICH WOULD COUNTER THE MANIPULATIVE INFLUENCE OF ELECTRONIC MEDIA
}

\author{
Yuliia Kyiashko \\ National State Tax Service University of Ukraine, \\ 31 Universytetska str., 08201, Irpin, Kyiv reg., Ukraine \\ e-mail: kiyashkoup@ukr.net \\ https://orcid.org/0000-0002-2110-3565
}

The purpose of this article is to determine the concept of factchec in Ukrainian information space. This is best explained by way of example of non-profit organizations activity. There are the most popular factchecking projects in Ukraine: VoxCheck, Stopfake.org, bez-brehni. com, slovoidilo.ua. As of late, the need for disclosure and analysis of public information from politicians has become more and more relevant. The problem is, most of them was lies from the start of their social and political activities. But exposing fake or manipulated images is quite possible with the proper tools and techniques.

Factcheckers played a crucial role in information and communications, a role that needed reinforcement in order to counter the manipulation, lies and distortion of facts of biased media groups.

The problem of biased media leads to the search for truth for mediausers. The audience needs clarification and media expertise. First of all, this is connected with the tendency of antiUkrainian propaganda in the context of Ukraine's political interactions on the international scene.

The research involves analyzing the factchecking concept that is currently used by nonprofit organizations, and considering the algorithm for exposing manipulative techniques, truth, halftruth and lies.

The article contains recommendations for the consumer of information in social mass media. It will contributes to furtherance of media literacy of the audience. tips are based on the analysis of manipulative techniques that are used most often in media reports. The results of this study became the basis of the video instruction scenario, which was transmitted on regional television.

The analysis of the basic factcheck concepts in modern Ukrainian media space has shown that the process of improving the checking and verification algorithm continues. The question of finding optimal forms and methods for disseminating the recommendations and instructions for the correct consumption of information flows, as well as improving the factcheck algorithm for exposing manipulative statements remains relevant and requires further research. Especially during the election campaign.

Key words: deep fake, lie, manipulation, media literacy, factcheck, fake, verification. 